\title{
A szülő és a gyermek közötti kapcsolattartás alapjogi és személyiségi jogi vetülete
}

\author{
szülő-gyermek kapcsolattartása - gyermeki jog - általános személyiségi jog - \\ családjogi személyiségvédelem
}

A gyermek önálló személyiség, akinek elképzelései, vágyai, érzései vannak, e személyiség kedvező irányba való fejlődése pedig jelentős mértékben függ szülei magatartásától. Személyisége egészséges fejlődésének és harmonikus kibontakoztatásának alapfeltétele, hogy a gyermek családi környezetben, boldog, szeretetteljes és megértő légkörben nőjön fel ${ }^{1}$ - abban az esetben is, ha szüleinek házassága véglegesen és helyrehozhatatlanul megromlik. ${ }^{2}$

A házasság felbontása esetén gyakran előfordul, hogy a bíróságok a kapcsolattartási jogot a bontóperek egyik járulékos kérdéseként kezelik, ${ }^{3}$ holott a gyermek jogainak és érdekeinek védelme egyáltalán nem jelent „járulékos kérdést”: vitathatatlan tény, hogy a gyermek szüleivel történő zavartalan kapcsolattartása személyiségének lényeges vonását képező, igen érzékeny szegmense.

A gyermek érdekeinek védelmét a szülői felügyelet - és a kapcsolattartás - kérdésében történő döntés során maximálisan tiszteletben kell tartani, és nem mellékesen, hanem kellő odafigyeléssel, felkészülten és felelősségteljesen kell határozni róla. ${ }^{4}$

A gyermek minél teljesebb körü védelme ugyanis olyan alapvető, elvi éllel megfogalmazott követelmény, amelyet a társadalom joggal támaszt mind a jogalkotással, mind pedig az ítélkezési gyakorlattal szemben. Ez a felismerés jut kifejezésre

\footnotetext{
* Dr. Szendrői Anna PhD-hallgató, Debreceni Egyetem, Marton Géza Állam- és Jogtudományi Doktori Iskola, annaszendroi@yahoo.com. A tanulmány az Igazságügyi Minisztérium jogászképzés színvonalának emelését célzó programjai keretében valósult meg.

1 1991. évi LXIV. törvény a Gyermek jogairól szóló, New Yorkban, 1989. november 20-án kelt Egyezmény kihirdetéséröl - Preambulum.

${ }^{2}$ A kapcsolattartási jog természetesen nemcsak elvált szülők gyermekeinek esetében létező jogosultság. Az élettársi kapcsolatból született, külön élő szülők gyermekei, valamint a családból kiemelt, nevelésbe vett gyermekek is jogosultak a külön élő szüleikkel történő kapcsolattartásra.

${ }^{3}$ Somfal Balázs: Kapcsolattartás, mint a gyermek emberi joga. HVG-ORAC, Budapest, 2009, 4.

${ }^{4}$ NAGY Andrea: Bővülő keretek - A kapcsolattartás szabályozása az új Ptk-ban. http://www.mabie.hu/index. php/cikkek-tanulmanyok/105-dr-nagy-andrea-bovulo-keretek-a-kapcsolattartas-szabalyozasa-az-uj-ptk-ban (2019. 04. 06.).
} 
az Alaptörvényben, a Polgári Törvénykönyvben (a továbbiakban: Ptk.) ${ }^{5}$ - annak Családjogi Könyvében (a továbbiakban: Csjk.) - és más jogszabályokban ${ }^{6}$ is. $^{7}$

A kapcsolattartási jog Janus-arcú jogintézmény: habár szabályait elsősorban magánjogi (polgári jogi) rendelkezések rögzítik, a jogintézmény legalább annyira közjogi természetü, mint magánjogi jellegü. ${ }^{8}$ A családjogi jogviszonyokban, hagyományosan a magánjog keretében meghatározott szülői felelősség körében a családvédelmi alapelvet olykor túlszárnyaló, a gyermek legjobb érdekének elve ${ }^{9}$ kiválthat közjogi, gyermekvédelmi intézkedéseket. Ez is az a pont, ahol a magánjog és közjog találkozik, illetve átfedést mutat. A két jogág célja jelen esetben egy és ugyanaz: a gyermek védelme. ${ }^{10}$

A tanulmány célja annak vizsgálata, hogy a kapcsolattartási jog hogyan illeszthető be az alkotmányjogi, illetve a polgári jogi védelem rendszerébe, milyen összefüggések fedezhetőek fel a két jogterület eszközeit illetően. Vizsgálatom tárgyát képezi továbbá, hogy az alkotmányjog és a polgári jog az általános szabályok keretei között, vagy alapjogi, illetőleg személyiségi jogi rangra emelve biztosítja-e a kapcsolattartási jog érvényesülését és védelmét.

A fogalmi alapvetést követően a vonatkozó joganyag és a témában releváns szakirodalom kvalitatív feldolgozását kísérelem meg. Elméleti téziseim igazolására a bírósági, valamint alkotmánybírósági gyakorlatot hívom segítségül: álláspontom szerint ugyanis a kapcsolattartási jog természete, más alapjogokkal és személyiségi jogokkal fennálló kapcsolata a bírósági esetjog megismerésén és feldolgozásán keresztül válik értelmezhetővé.

\footnotetext{
${ }^{5}$ A Polgári Törvénykönyvről szóló 2013. évi V. törvény.

${ }^{6}$ A teljesség igénye nélkül lásd: a Büntető Törvénykönyvröl szóló 2012. évi C. törvény, a gyermekek védelméről és a gyámügyi igazgatásról szóló 1997. évi XXXI. törvény, a gyermekvédelmi és gyámügyi feladat- és hatáskörök ellátásáról, valamint a gyámhatóság szervezetéről és illetékességéről szóló 331/2006. (XII. 23.) Korm. rendelet, a gyermekvédelmi és gyámügyi eljárásról szóló 149/1997. (IX. 10.) Korm. rendelet. A nemzeti jog szempontjából is releváns uniós és nemzetközi jogi joganyag a határokon átívelő kapcsolattartásra vonatkozóan: a Tanács 2201/2003/EK rendelete a házassági ügyekben és a szülői felelősségre vonatkozó eljárásokban a joghatóságról, valamint a határozatok elismeréséről és végrehajtásáról, illetve az 1347/2000/EK rendelet hatályon kívül helyezéséről (az ún. Brüsszel II.a rendelet), a Gyermekek Jogellenes Külföldre Vitelének Polgári Jogi Vonatkozásairól szóló Hágai Egyezmény (1980), a gyermekek feletti felügyeleti jogot érintő határozatok elismeréséröl és végrehajtásáról, valamint a felügyeleti viszonyok helyreállításáról szóló Luxemburgi Egyezmény (1980), a Gyermek jogairól szóló New Yorki Egyezmény (1989), a szülői felelősséggel és a gyermekek védelmét szolgáló intézkedésekkel kapcsolatos együttműködésről, valamint az ilyen ügyekre irányadó joghatóságról, alkalmazandó jogról, elismerésről és végrehajtásról szóló Hágai Egyezmény (1996).

${ }^{7}$ A Legfelsőbb Bíróság gyermek elhelyezésével kapcsolatos szempontokról szóló 17. számú irányelve, a továbbiakban: 17. számú irányelv. Az irányelv a Kúria 1/2014. számú PJE határozata alapján az új Ptk. hatálya alatt már nem tekinthető irányadónak, tekintettel arra, hogy a „gyermekelhelyezés” jogintézménye más tartalommal került meghatározásra a Ptk.-ban. Ennek ellenére az irányelvben szereplő szempontrendszer több eleme a bírói gyakorlat számára továbbra is hivatkozási alapként szolgál.

${ }^{8}$ A szülö és a gyermek közötti kapcsolattartás magánjogi fogalmát a Ptk. 4:178. §-a rögzíti kapcsolattartási jogként, közjogi fogalmának, valamint annak tartalmi elemeinek kimunkálása az Alkotmánybíróság jogértelmező és jogfejlesztő tevékenységének eredménye.

${ }^{9}$ A gyermek legjobb vagy mindenekfelett álló érdekének elve a nemzetközi dokumentumokban megjelenő fogalom, a Csjk. ehelyett a „gyermek érdekének védelme” elnevezésű alapelvet tartalmazza. (Ptk. 4:2. §).

10 Somfal Balázs: Családjogi és/vagy gyermekvédelmi jogviszony. Családi Jog, 2013/4, 32.
} 


\section{A kapcsolattartási jog mint gyermeki jog}

A kapcsolattartási jogot mind a jogirodalomban, mind pedig a joggyakorlatban hagyományosan gyermeki jogként - ezzel összefüggésben pedig szülöi kötelezettségként - kategorizálják. A gyermekek védelmének szükségessége kétségbevonhatatlan érvényű állítás, s ennek megfelelően napjainkban a gyermek érdekének és jogainak fokozottabb érvényesülése figyelhető meg mind nemzetközi, mind európai, mind pedig hazai viszonylatban. ${ }^{11}$

Tény, hogy a gyermek: ember. Magától értetődő tehát, hogy az emberi jogok - mint minden emberi lény alapvető jogait szabályozó nemzetközi okmányokban biztosított jogok - megilletik a gyermekeket is. ${ }^{12} \mathrm{~A}$ gyermekek azonban életkorukból és kiszolgáltatottságukból adódó speciális helyzetük miatt többletvédelemre jogosultak. ${ }^{13}$ Ezt a védelmet hivatottak biztosítani a gyermekjogok, melyek - konkrét kötelezettségeket és elvárásokat meghatározva - kijelölik a felelős és jogkövető szülői viselkedés és a bírósági eljárások kereteit, ${ }^{14}$ valamint determinálják a jogalkotás irányait is.

Általánosságban megállapítható, hogy a gyermek védelme komplex jogi megközelítést igényel, a minél szélesebb körú védelem biztosítása érdekében pedig a gyermeki jogoknak át kell hatniuk a jogrendszer egészét.

Ez a kapcsolattartási jog esetében sincs másképp. A fogalmi sokszínüség a kapcsolattartás jogának vonatkozásában is kiemelt hangsúlyt kap: a kapcsolattartáshoz füződő jog mint nemzetközi egyezményekben deklarált gyermeki jog (második generációs emberi jog) egyrészt az alkotmányos rend által védett jogosultság, másrészt pedig a polgári jogi szabályok által érvényre juttatott jog is egyben.

A nemzetközi jogi egyezményekben rögzített emberi (gyermeki) jogok ugyanis nem automatikusan, hanem alapjogi és személyiségi jogi elismerést nyerve épülnek be a nemzeti jogrendszerekbe.

E transzformáció az emberi jogok és az alkotmányos alapjogok között magától értetődő: az emberi jogok az alkotmányos alapjogokat jogállam esetén direkt módon meghatározzák, ami technikailag is könnyen kivitelezhető, hiszen az emberi jogok közvetett címzettje ${ }^{15}$ és az alkotmány kibocsátója egyaránt az állam. ${ }^{16}$

$S$ hogy mi a kapcsolat az emberi jogok és a személyiségi jogok között? Jóval szorosabb, mint gondolnánk: az emberi jogok lényegében az egész emberiség által elfogadott személyiségi jogok is, melyeket nemzetközi szerződések rögzítenek. ${ }^{17}$

\footnotetext{
${ }^{11}$ FAZEKAS Ágota: A gyermeki jogok érvényesülésének új tendenciái a családjogban. Családi Jog, 2016/2, 1.

${ }^{12}$ Rózsás Eszter: A gyermekjogok tartalma, érvényesülése és védelme. Doktori (PhD) értekezés, Pécs, 2008, 11.

${ }^{13}$ A szakirodalom ezt a különös védelmet pozitív diszkriminációnak értékeli. 9/1990. (IV. 25.) AB határozat, ABH 1990, 46.

${ }^{14}$ GYuRKó Szilvia: A házassági bontóperek lélektana és a gyermekjogok érvényesülése váláskor. Családi Jog, 2015/2, 12.

${ }^{15} \mathrm{Az}$ emberi jogok elsődleges címzettjei magától értetődően az emberek, azonban közvetett címzettjei az államok, melyek nemzetközi szerződésekhez történő csatlakozásukkal arra vállalnak kötelezettséget, hogy saját belső jogrendjükben - elsősorban alkotmányukban, illetve általános törvényeikben - a deklarált emberi jogokat biztosítják állampolgáraik számára. LENKovics Barnabás-SzéKELY László: A személyi jog vázlata. Eötvös József Könyvkiadó, Budapest, 2008, 100.

${ }^{17}$ LenKovics-Székely: i. m., 100.
}

$84{ }^{16}$ LENKOVICS-SZÉKELYY: i. m., 101. 
Az emberi jogok időnként tágabb kategóriát jelentenek az ember szubjektumához tapadó személyiségi jogokhoz képest, de kétséget kizáróan kijelenthető, hogy az emberi jogok polgári jogi vetülete nem más, mint a személyiségi jog. ${ }^{18}$

Összegezve megállapítható tehát, ${ }^{19}$ hogy az egyetemes nyilatkozatokban deklarált emberi jogok konkrét megfogalmazást nyernek az Alaptörvény alapjogi katalógusában, s ezek magánjogi jogviszonyokban történő érvényesülését biztosítja - más jogágakkal szoros és párhuzamos munkamegosztásban - a polgári jog által biztosított személyiségi jogvédelem. Mindez jogunk emberközpontúságának kifejeződése. $^{20}$

A továbbiakban vizsgálódásom arra irányul, hogy a hazánk által (is) ratifikált nemzetközi egyezményekben ${ }^{21}$ elismert kapcsolattartási jog mint emberi jog, érvényesítése és védelme milyen formában jelenik meg a hazai jogi gondolkodásban, valamint a tételes közjogi (alkotmányjogi) és magánjogi (polgári jogi) szabályok rendszerében.

\section{A kapcsolattartási jog alapjogi minősége}

A gyermeki jogok térhódításával párhuzamosan a család, valamint a gyermek érdekét szolgáló elvek és jogintézmények - a családvédelem, valamint a gyermek legföbb érdekének elve - az alkotmányos rendelkezések szintjén is megjelentek.

Ennek megfelelően az Alaptörvény expressis verbis deklarálja, hogy az állam a házasság és a család védelmére köteles ${ }^{22} \mathrm{~s}$ hitet tesz a család mint alapvető érték mellett. Gyakran úgy túnik azonban, hogy ezen értékkötelezettség megmarad az ünnepélyes deklarációk ${ }^{23}$ szintjén, $s$ a jog szinte tehetetlenül szembesül a közösségeket szétbontó társadalmi folyamatokkal. ${ }^{24}$

A házasság felbontása kétségbevonhatatlan változást idéz elő a családi kapcsolatok addig fennáló rendjében, s alapvetően befolyásolja a szülö-gyermek kapcsolatot is. Magától értetődő, hogy a házassági kötelék felbontásával a gyermek sor-

${ }^{18}$ FÉzer Tamás: A nem vagyoni (erkölcsi) sérelmek megítélése a polgári jogban. HVG-ORAC, Budapest, 2011, 19.

19 Sólyom László az ember - természetjogban gyökerező - veleszületett, elidegeníthetetlen jogait egyenesen a személyiségi jogok előképeinek tekinti. A személyiségi jogok és az alapjogok kapcsolatát illetően példákkal illusztrálja azok relatív összeolvadását, mely meglátása szerint elsősorban az általános személyiségi jog esetében érhető tetten. Sóıyom László: A személyiségi jogok elmélete. Közigazgatási és Jogi Könyvkiadó, Budapest, 1983, 41-44.

20 LeNKOVICS-SzÉKELY: i. m., 96-97.

${ }^{21}$ A teljesség igénye nélkül: az Emberi Jogok Európai Egyezménye (1950), az Emberi Jogok és Alapvető Szabadságok Védelméről szóló Római Egyezmény (1950), a Gyermekek Jogairól szóló New York-i Egyezmény (1989), az Európai Unió Alapjogi Kartája (2000), az Európa Tanács gyermekekkel való kapcsolattartásról szóló Egyezménye (2003).

22 Alaptörvény L. cikk (1) Magyarország védi a házasság intézményét mint férfi és nő között, önkéntes elhatározás alapján létrejött életközösséget, valamint a családot mint a nemzet fennmaradásának alapját. A családi kapcsolat alapja a házasság, illetve a szülö-gyermek viszony.

${ }^{23}$ Alaptörvény, Nemzeti Hitvallás: „Valljuk, hogy együttélésünk legfontosabb keretei a család és a nemzet, összetartozásunk alapvető értékei a hüség, a hit és a szeretet."

${ }^{24}$ SchANDA Balázs: A jog lehetőségei a család védelmére. Iustum Aequum Salutare, 2012/2, 77. 
sáért fennálló szülői felelősség sem az apa, sem pedig az anya vonatkozásában nem szűnik meg. A gyermek nevelésében való további közreműködést, a gyermek sorsának figyelemmel kísérését, valamint a gyermekkel fennálló érzelmi kötelék megőrzését a kapcsolattartási jog hivatott szolgálni.

Az Alaptörvény Szabadság és felelösség cím alatt rögzíti az embert megillető alapvető jogokat. Habár a kapcsolattartás joga az Alaptörvény alapjogi katalógusában nem kerül rögzítésre, az mégis alapjogi elismeréssel bír. Az Alkotmánybíróság már egy korai döntésében rögzítette, hogy a házasságra és a családra - így a kapcsolattartásra is - vonatkozó szabályok az alapvető jogokra és kötelezettségekre tartoznak, így tehát alapjogi védelemben kell hogy részesüljenek. ${ }^{25}$

A gyermek ugyanis ember, akit minden olyan alkotmányos alapjog megillet, mint mindenki mást. Ahhoz azonban, hogy a jogok teljességével képes legyen élni, biztosítani kell számára az életkorának megfelelő valamennyi feltételt a felnőtté válásához. ${ }^{26}$

Habár a fentieket az Alkotmánybíróság a gyermek tartására vonatkozó szabályokkal összefüggésben mondta ki, az Alkotmánybíróság felfogása szerint a felnőtté váláshoz szükséges feltételek körébe nemcsak az anyagi, hanem a lelki, szellemi, erkölcsi feltételek is beletartoznak, köztük a gyermek külön élő szülőjével való kapcsolattartása (kialakítása, fenntartása) is. ${ }^{27}$

A továbbiakban a kapcsolattartás jogának vizsgálatát - a jog természetét, más alapvető jogokkal való kapcsolatát - az Alkotmánybíróság vonatkozó gyakorlatának elemzése útján kísérelem meg.

A kapcsolattartási jog - ahogyan más, nem nevesített alapvető jogosultságok alapjogi minőségének elismerésére az emberi méltósághoz füződő jog anyajogként történő felfogása teremt lehetőséget. Az egyenlő méltóság alapjogán esne ugyanis csorba, amennyiben a jog a személyiség valamely (jogi értelemben strukturált) rétegét, tartalmi vonatkozását kedvezményezné, fölébe helyezné egy másiknak. ${ }^{28}$ E felfogásnak megfelelően tehát az Alkotmánybíróság az emberi méltóságból - avagy annak aspektusaként megnevezett személyiség szabad kibontakoztatásához füződő jogból, az önrendelkezés szabadságához való jogból, az általános cselekvési szabadságból, a magánszférához való jogból ${ }^{29}$ - levezethető jogosultságokat is alapjogi rangra emeli.

Az Alkotmánybíróság a kapcsolattartási jogot az Alaptörvény gyermekekre vonatkozó $^{30}$ speciális rendelkezéséböl eredezteti, s a szülöi felügyeleti jogok kontextusában értelmezi; a gyermek gondozásához, neveléshez füződő jogára pedig az Alaptör-

25 4/1990. (III. 4.) AB határozat, $A B H$ 1990, 28.

26 995/B/1990. AB határozat, AB 1993, 515, III. 7. pont.

27 394/B/2006. AB határozat, $A B H 2008,2364$.

28 34/1992. (VI. 1.) $A B$ határozat, $A B$ 1992, 192, III. 4.1. pont.

29 8/1990. (IV. 23.) AB határozat, ABH 1990, 4.

${ }^{30}$ Alaptörvény XVI. cikk (1) Minden gyermeknek joga van a megfelelő testi, szellemi és erkölcsi fejlődéséhez szükséges védelemhez és gondoskodáshoz. 
vényben rögzített, magán- és családi élethez füződő jog ${ }^{31}$ szegmenseként ${ }^{32}$ tekint. $^{33}$ Az Alkotmánybíróság több határozatában kiemelte, hogy a gyermeknek a megfelelő testi, szellemi és erkölcsi fejlődéséhez szükséges védelemhez és gondoskodáshoz való joga az állam alkotmányos kötelességét alapozza meg a gyermek fejlődésének védelme érdekében. ${ }^{34}$

Egy korai indítványban a kapcsolattartási jog a diszkrimináció tilalmával összefüggésben merült fel. Az indítványozók az elvált apák pozíciójából indultak ki, kérelmük pedig a vonatkozó rendelkezések alkotmányellenességének utólagos megállapítására, továbbá azok megsemmisítésére irányult. Valamennyi jogszabályhely tekintetében az elvált apák, illetve volt férjek hátrányos megkülönböztetésére hivatkoztak; azt sérelmezték, hogy csak annak a szülőnek marad fenn a szülői felügyeleti joga - holott véleményük szerint a szülői felügyeleti jog korlátozhatatlan alapjog -, akinél a gyermeket elhelyezték, ${ }^{35}$ hivatkoztak továbbá arra, hogy a külön élő szülővel szemben a kapcsolattartásra vonatkozó rendelkezések diszkriminatívnak tekinthetők. ${ }^{36}$

Az Alkotmánybíróság álláspontja szerint a külön élő szülő felügyeleti jogának szünetelése ${ }^{37}$ a különélés tényéböl következik, és csupán részlegesnek mondható, hiszen a gyermek testi fejlődési feltételeinek biztosítása, a róla való gondoskodás a külön élő szülő kötelessége is. Ilyenkor a napi folyamatos gondozás teljesítése ütközik akadályba a távollét folytán. A gyermekkel való kapcsolattartás (láthatás) azonban ebben az esetben is biztosított, sőt, ez a külön élő szülö kötelessége is a törvény szerint. A szünetelés részlegességét maga a törvény emeli ki, amikor a különélés alatt is biztosítja a gyermek sorsát érintő lényeges kérdések esetében az együttes döntést a szülők számára. Mindezekre tekintettel az Alkotmánybíróság megállapította, hogy a szülői felügyelettel és a gyermekkel való kapcsolattartással

${ }^{31}$ Alaptörvény VI. cikk (1) Mindenkinek joga van ahhoz, hogy magán- és családi életét, otthonát, kapcsolattartását és jó hírnevét tiszteletben tartsák. A véleménynyilvánítás szabadsága és a gyülekezési jog gyakorlása nem járhat mások magán- és családi életének, valamint otthonának sérelmével.

32 A 2018. augusztus 1. óta hatályos, a magánélet védelméről szóló 2018. évi LIII. törvény a magánélethez füződő jog - valamint szegmenseinek, többek között a családi élethez füződő jognak - fokozott védelmét hivatott biztosítani. A törvény deklarálja, hogy a magánélethez való jog az ember veleszületett méltóságából ered, amely mindenkit megillet. Ezen jog elengedhetetlen az önazonosság kiteljesedéséhez, hiszen az emberi személyiség érinthetetlen tartományát határolja körül.

${ }_{33}$ 3312/2017. (XI. 30.) AB határozat, ABH 2017, 1856, 40. pont: „Emellett az Alaptörvény VI. cikk (1) bekezdése a gyermek és szülő kapcsolattartáshoz való jogát kívánja biztosítani."

34 21/1996. (V. 17.) AB határozat, $A B H$ 1996, 74.

${ }^{35}$ Az új Ptk. a szülők vonatkozásában megszüntette a gyermekelhelyezés fogalmának használatát, azt csupán harmadik személynél történő elhelyezés esetén alkalmazza. A szülők tekintetében a szülői felügyeleti jogok közös vagy egyik szülő általi gyakorlásáról beszélhetünk. (Ptk. 4:164-4:172. §.)

${ }^{36}$ SzEIBERT Orsolya: Kapcsolattartás a gyermek és a különélő szülő között, különös tekintettel az alkotmánybírósági és ombudsmani gyakorlatra. In: Köhidi Ákos-Keserű Barna Arnold (szerk.): Tanulmányok a 65 éves Lenkovics Barnabás tiszteletére. Eötvös József Könyv- és Lapkiadó Bt.; Széchenyi István Egyetem Deák Ferenc Állam- és Jogtudományi Kara, Győr-Budapest, 2015, 476.

${ }^{37}$ Az érintett alkotmánybírósági határozat a házasságról, a családról és a gyámságról szóló 1952. évi IV. törvény hatálya idején fennálló állapotot rögzíti. A Ptk. jelenleg hatályos szabályai alapján a külön élő szülő szülői felügyeleti joga nem szünetel. A szülői felügyeleti jog szünetelésének eseteit a Ptk. 4:186. §-a tartalmazza. A hatályos Ptk. megalkotásával összefüggő kodifikációs folyamat a kapcsolattartás magánjogi szabályait sem hagyta érintetlenül. A változásokról bővebben: KöRös András: A családjog jövője - II. rész. Családi Jog, 2013/4, 6 . 
összefüggő és az indítványokkal érintett jogszabályok nem ütköznek alkotmányos rendelkezésekbe. E körben a szülők jogának korlátozásai a gyermek érdekében állóak és a védett érdekkel arányosak. ${ }^{38}$

Egy másik indítványban a kapcsolattartás jogát a vérségi származás megismeréséhez füződő joggal hozták közvetlen összefüggésbe. Az indítványozó szerint az általános személyiségi jogból fakad a személyi integritáshoz való jog, amelyből levezethető a vérségi származás kiderítésének a joga. Az indítvány szerint ezek a jogok összefüggésbe hozhatóak a családi kapcsolatok kialakításával és fenntartásával, hiszen a gyermek elhelyezésére rendszerint vele vérségi kapcsolatban levő személynél, tipikusan az egyik szülönél kerülhetett sor, és a gyermek föszabály szerint vérségi kapcsolatban volt a kapcsolattartás jogosultjával, a másik szülővel is.

Az Alkotmánybíróság ezt a nézetet is elvetette. Érvelésében kifejtette, hogy az általános személyiségi jogból levezetett vérségi származás megismerésére vonatkozó jogból nem következik semmilyen összefüggés a kapcsolattartási jogra, valamint annak korlátozására, vagy kizárására vonatkozóan. Különösen érvényes ez abban az esetben, ha nem vérségi kapcsolatról, hanem szociológiai értelemben vett családról van szó, hiszen az Alkotmánybíróság állandó gyakorlatának megfelelően a tényleges családi gondoskodáshoz való jog nemcsak a vérségi családban valósulhat meg. Az indítványozó érveinek elutasítása mellett az Alkotmánybíróság hangsúlyozta, hogy a kapcsolattartási jog a gyermek gondoskodáshoz való, valamint a szülő gyermekneveléséhez füződő jogából fakad. Eszerint a gyermek jogosult arra, hogy külön élő szülőjével személyes és közvetlen kapcsolatot tartson fenn, ugyanakkor a kapcsolattartás joga a szülő kötelezettsége is: a gyermekétől külön élő szülőnek nemcsak joga, hanem kötelessége is, hogy gyermekével rendszeresen érintkezzen, fejlődését figyelemmel kísérje és segítse, a gyermeket nevelő szülő - vagy más személy ${ }^{39}$ - pedig köteles a zavartalan kapcsolattartást biztosítani. ${ }^{40}$

Az Alkotmánybíróság felfogásából tehát egyértelműen kirajzolódik az az elv, amely alapján a kapcsolattartás nem csupán a gyermeket megillető jog, hanem a szülő oldalán fennálló - a szülői felügyeleti jogból levezethető - jogosultság és kötelezettség is egyben.

A kapcsolattartásnak mind a gyermek, mind pedig a külön élő szülö érdekében megfogalmazott szabálya a gyermeknek a külön élő szülővel való érintkezését, illetőleg ennek a szülőnek a gyermek nevelésében való közremüködését hivatott biztosítani akkor is, ha utóbbi a gyermek gondozásában közvetlenül nem vesz részt. Mivel a kapcsolattartás mindkét alanyának jogai védelemre szorulnak, a jogszabályi rendelkezések a gyermeknek a - külön élő szülő részéről történő - gondoskodáshoz való joga, míg a külön élő szülőnek a gyermek nevelésében való közreműködéséhez füződő joga gyakorlásának garanciáit teremtik meg. ${ }^{41}$

Az Alkotmánybíróság határozataiból kétségkívül megállapítható, hogy a kapcsolattartási jog - a magán- és családi élethez fűződő jog keretében - a gyermeket megillető gondoskodáshoz és neveléshez való jogosultságából, s ennek inverze, a

\footnotetext{
38 995/B/1990. AB határozat, ABH 1993, 515.

${ }^{39}$ A kapcsolattartásra jogosult hozzátartozók körét a Ptk. 4:179. §-a rögzíti.

40 394/B/2006. AB határozat, AB 2008, 2364, III. 2. pont.

41 941/E/2005. AB határozat, AB 2006, 2148, III. pont.
} 
szülő oldalán fennálló gyermeknevelési kötelezettségből vezethető le. A szülőkkel fennálló kapcsolat nélkülözhetetlen a gyermek testi-lelki egészsége, személyiségfejlődése szempontjából, magától értetődő tehát, hogy a kapcsolattartási jog kitüntetett szereppel bír az alapjogok körében.

Mint minden alapvető jog, a kapcsolattartás joga sem jelent azonban abszolút, feltétlen érvényesülést kívánó értéket. Amennyiben más alkotmányosan védendő joggal ütközik, a szükségességi-arányossági teszt lefolytatása útján mérlegelni kell annak korlátozhatóságát. ${ }^{42}$ Egy alkotmányjogi panaszban ${ }^{43}$ az egyik szülő oldalán fennálló magánszféra, magántitok, illetve levéltitok védelméhez füződő jog, valamint a másik szülöt megillető kapcsolattartási jog összemérésére került sor. Az indítványban leírtak alapján az apa az anya tudta nélkül feltörte annak számítógépét, s elolvasta az ott tárolt leveleket és dokumentumokat, hogy megakadályozza a közös gyermekek külföldre vitelét. A vizsgálat során meg kellett állapítani, hogy az indítványozó magántitokhoz való jogával szemben kellő súlyú alkotmányos indok-e az apát mint szülőt megillető kapcsolattartáshoz való jognak, valamint szülői felügyeleti és nevelési jogna ${ }^{44}$ a védelme, amely igazolhatja a magántitok korlátozását. Nem képezte vita tárgyát az, hogy az indítványozó alapjogát sértette az apa magatartása. Ugyanakkor az apának más lehetősége nem volt a szülöi felügyeleti jogának, illetve nevelési jogának védelmére, és legföképp felügyeleti kötelezettségének biztosítására, hiszen az indítványozó szülő gyermekeik sorsáról egyedül, a másik szülő beleegyezése nélkül hozott vagy legalábbis hozhatott volna fontos döntést. A gyermekek sorsáról, neveléséről való döntés mindkét szülő egységes akarat-elhatározása alapján jöhet létre, azaz a gyermek külföldre viteléhez szükséges a külön élő szülő erre vonatkozó beleegyezése is.

Az Alkotmánybíróság az alapjog-korlátozás szükségességével összefüggésben kimondta, hogy a közös gyermekek sorsa nem kizárólag az egyik szülő magánügye, és ennél fogva magántitka. Mindezek alapján az Alkotmánybíróság megállapította, hogy az apa a szülöi felügyeleti, valamint a gyermekkel történő kapcsolattartáshoz füződő jogának védelme prioritást élvezett a magánszféra jogában gyökerező magán- és levéltitokhoz füződő joggal szemben.

Összességében megállapítható, hogy a kapcsolattartási jog alapjogi minősége nem vitatott, az az Alaptörvény családvédelmi rendelkezéseiből közvetlenül levezethető jogintézménynek tekinthető. A kapcsolattartás alapjoga mind a szülö, mind pedig a gyermek oldalán fennálló jogosultságként értelmezhető, a gyermek jólétének, egészséges személyiségfejlődésének alappilléreként. Ebböl kifolyólag a szülő oldalán fennálló kapcsolattartási jog egyben szülői kötelezettséget is jelent.

Álláspontom szerint a kapcsolattartási jog alapjogként történő elismerése célszerủ és indokolt, hiszen alapjogi rangra emelésével hatékony jogi garanciák révén érvényesülő, ténylegesen kikényszeríthető jogosultsággá válik.

\footnotetext{
${ }^{42}$ Alaptörvény I. cikk (3) Az alapvető jogokra és kötelezettségekre vonatkozó szabályokat törvény állapítja meg. Alapvető jog más alapvető jog érvényesülése vagy valamely alkotmányos érték védelme érdekében, a feltétlenül szükséges mértékben, az elérni kívánt céllal arányosan, az alapvető jog lényeges tartalmának tiszteletben tartásával korlátozható.

43 3312/2017. (XI. 30.) AB határozat, ABH 2017, 1856.

${ }^{44}$ Alaptörvény VI. cikk (1) bekezdés, XVI. cikk (1) bekezdés.
} 
Habár az alapjogok elsősorban az állami beavatkozásokkal szemben nyújtanak védelmet, magánjogi jogviszonyokra gyakorolt hatásuk sem elhanyagolható. Az utóbbi időszakban ugyanis mind a jogirodalomban, ${ }^{45}$ mind pedig a bírói gyakorlatban megfigyelhető a polgári jogi és az alkotmányos jogvédelem összeolvadása ${ }^{46} \mathrm{~A}$ jogági határok relativizálódása, a magánjog és közjog közötti ellentét viszonylagossá válása, egyes közjogi mozgásformák elvándorlása a magánjogiak felé, ugyanakkor a civiljogi gondolkodás mind erőteljesebb munkálkodása a közjogban ${ }^{47}$ a klasszikus jogági struktúrák fellazulását ${ }^{48} \mathrm{~s}$ ennek megfelelően a polgári jogi és alkotmányos jogvédelem szorosabb kapcsolatának kialakulását eredményezte. Felfedezhető egyfajta kapcsolódási pont a személyiségi jogok és az alkotmányos jogok között: a polgári jog által védett, magánszemélyek jogvitái során érvényre juttatott személyiségi jogok alapvetően az alkotmányos szabályok által oltalom alá helyezett alapvető jogainak írott és íratlan katalógusára épülnek. ${ }^{49} \mathrm{Az}$ alapjogok polgári jogi személyiségvédelemre gyakorolt hatása tehát vitathatatlan - az pedig, hogy a kapcsolattartási jog alapjogi természetének deklarálása maga után vonja-e e személyiségi jogi minőségének elismerését, a kapcsolattartási jog magánjogi szabályok kontextusában történő elemzése útján állapítható meg.

\section{A kapcsolattartási jog személyiségi jogi minősége}

Habár a kapcsolattartási jog alapjogi minősége megkérdőjelezhetetlen, elöljáróban kijelenthető, hogy személyiségi jogi mivoltát illetően a megválaszolatlan kérdések többségben vannak a vitathatatlan megállapításokhoz képest. A jogintézmény személyiségi jogi természete ugyanis a jogtudományban és a joggyakorlatban is egymástól élesen elkülönülő álláspontokból fakadó, messzemenő vitákat generál.

A kapcsolattartás magánjogi szabályainak ${ }^{50}$ vizsgálatát megelőzően is megállapítható, hogy a család védelme nemcsak az alkotmányjogban, hanem a polgári jogban is kitüntetett szereppel bír. A kiemelt figyelmet elsősorban az indokolja, hogy a család biztosítja azt a környezetet, amelyben a gyermek születésének, felnevelésének legkedvezőbb feltételei megteremthetőek. ${ }^{51}$

${ }^{45}$ A közjog és magánjog jogelméleti szempontú elhatárolási nehézségeivel kapcsolatban JAKAB András: Közjog, magánjog, polgári jog - a dogmatikatörténet Próteuszai. Állam- és jogtudomány, 2007/1, 3-27.

${ }^{46}$ PETRIK Ferenc: A személyiség jogi védelme. A sajtó-helyreigazítás. HVG-ORAC, Budapest, 2001, 34.

${ }^{47}$ Lábady Tamás meglátása szerint a vonatkozó alkotmánybírósági gyakorlat azt a tendenciát mutatja, hogy a magánjog kifejezetten a személyi jogok körében hasít ki egyre nagyobb szeletet a közjogból. A véleménynyilvánítás szabadságával kapcsolatos a 30/1992. (V. 26.) AB határozat, melyben rögzítésre került, hogy a közösségek méltóságának hatékony védelmére - a büntetőjogon túl - más jogi eszköz, például a nem vagyoni kártérítés alkalmazási lehetőségeinek bővítése is alkalmas. LÁBADY Tamás: Alkotmányjogi hatások a készülő Ptk. szabályaira. Polgári Jogi Kodifikáció, 2000/2, 13-19.

${ }^{48}$ LÁBADY Tamás: A magyar magánjog (polgári jog) általános része. Dialóg Campus, Budapest-Pécs, 2000, 26-27.

49 Petrik: i. m., 34.

${ }^{50}$ A kapcsolattartás polgári jogi szabályairól BARzó Tímea: A magyar család jogi rendje. Patrocínium, Budapest, 2017, 472-479.

51 17. számú irányelv. 
A gyermek - házasság felbontását követő - családi környezetben való felnevelkedéséhez és korábbi kapcsolatai megőrzéséhez való joga a polgári jogban (magánjogban) is elvi jelentőségü tétel, ${ }^{52}$ amely már a 19 . századi polgári jogi jogforrásokban is fellelhető volt.

Mind a házassági jogról szóló 1894. évi XXXI. törvénycikk, ${ }^{53}$ mind pedig az 1928. évi magánjogi törvényjavaslat ${ }^{54}$ rögzítette a szülők kapcsolattartáshoz füződő jogát, érintkezési jogként. A házasságról, a családról és a gyámságról szóló 1952. évi IV. törvény is tartalmazta a külön élő szülő kapcsolattartási jogosultságát, ebben az időben a bírói gyakorlat azonban az érintkezési jog helyett a láthatási jog fogalmát kezdte el bevezetni a köztudatba. Az 1986-os Csjt. Novella egyik jelentős módosító rendelkezése alapján a külön élő szülőnek nemcsak joga, hanem kötelessége is lett a gyermekével való rendszeres kapcsolattartás, a Csjt. 1995-ös módosítása után pedig a törvényszöveg kiegészült a gyermek kapcsolattartási jogosultságával is. ${ }^{55}$ A jelenleg hatályos Ptk. magától értetődően rögzíti a kapcsolattartás polgári jogi szabályait, ${ }^{56}$ mint a gyermek és szülő oldalán fennálló jogot, és egyben a szülő oldalán fennálló kötelezettséget. Ennek megfelelően a Csjk. alapelvként rögzíti a gyermek korábbi családi kapcsolatai fenntartásához füződő jogát, ${ }^{57}$ majd a szülői felügyeleti jogra vonatkozó szabályok körében, a 4. pontban részletezi a kapcsolattartásra vonatkozó főbb szabályokat.

A kapcsolattartás joga tehát a családjogi szabályok által védett érték, kérdés azonban, hogy a polgári jog egyéb eszközökkel - személyiségvédelem útján - garantálja-e a jog védelmét. A továbbiakban a vonatkozó bírósági határozatok elemzése útján arra keresem a választ, hogy a kapcsolattartási jog elismerhető-e személyiségi jogként, s hogyan kapcsolódik más, a családi jogviszonyok körében értékelt személyiségi jogokhoz.

Manapság mind a jogirodalomban, mind pedig a joggyakorlatban megoszlanak a vélemények a tekintetben, hogy a kapcsolattartási jog újonnan elismert, nevesített személyiségi jogként kategorizálható-e. E polémia indoka abban rejlik, hogy a Ptk. 2016-ban ${ }^{58}$ módosított szövege, valamint a magánélet védelméről szóló 2018. évi LIII. törvény is nevesített személyiségi jogként tartalmazza a kapcsolattartás tiszte-

${ }^{52}$ BARzó Tímea: A családjog alapelvei és érvényesülésük nehézségei. Miskolci Jogi Szemle, 2017. évi különszám, 48.

${ }^{53} \mathrm{Ht}$. 103. § „A szülő a gondviselésére nem bizott gyermekével is rendszerint érintkezhetik és nevelését ellenőrizheti. Az érintkezés módját szükség esetén a gyámhatóság állapítja meg, mely az érintkezést a gyermek nyilvánvaló érdekében ki is zárhatja."

${ }^{54}$ Mjt. 288. § „A szülőnek akkor is joga van gyermekével érintkezni, ha szülői hatalma megszünt vagy szünetel, vagy ha a gyermek gondviselése a másik szülöre vagy harmadik személyre van bízva."

${ }^{55}$ Csjt. 92. § (1) „A gyermeknek joga, hogy különélő szülőjével személyes és közvetlen kapcsolatot tartson fenn. A gyermekétől különélő szülő joga és kötelessége, hogy gyermekével kapcsolatot tartson fenn, vele rendszeresen érintkezzen (a kapcsolattartás joga). A gyermeket nevelő szülő vagy más személy köteles a zavartalan kapcsolattartást biztosítani."

56 Ptk. 4:178. §.

57 Ptk. 4:2. § (4) „A gyermeknek a saját családjában, illetve a családi környezetben nevelkedéséhez és a korábbi családi kapcsolatai fenntartásához füződő jogát törvényben meghatározott esetben, kivételesen és a gyermek érdekében lehet korlátozni."

${ }^{58}$ A Polgári Törvénykönyvről szóló 2013. évi V. törvény módosításáról szóló 2016. évi LXXVII. törvény. 
letben tartásához füződő jogot. Álláspontom szerint különbséget kell tennünk azonban a szülö-gyermek relációjában érvényesülő kapcsolattartási jog, valamint a Ptk. ${ }^{59}$ és a magánélet védelméről szóló törvény ${ }^{60}$ által rögzített kapcsolattartás tiszteletben tartásához füződő jog között. Véleményem szerint ez utóbbi ugyanis az írásbeli és szóbeli közlések, valamint egyéb kommunikációs eszközök útján átadott információk védelmére, harmadik személy általi meg nem ismerhetőségére vonatkozik.

E felfogás mentén a továbbiakban azt vizsgálom, hogy a kapcsolattartás joga más nevesített személyiségi jogból - továbbá az emberi méltósághoz füződő jogból, az ún. általános személyiségi jogból - levezethetö-e.

Hazánkban az általános személyiségi jogok védelmének alkotmányos gyökerei vannak. Az általános személyiségi jog - az emberi méltósághoz való alkotmányos alapjog magánjogi megfelelője - az alkotmánybírósági gyakorlat által kimunkált fogalom. ${ }^{61} \mathrm{~A}$ magyar jogalkotás igyekszik kiemelt figyelmet fordítani arra, hogy az egyes alapjogi rendelkezések a mindennapi és konkrét jogviszonyokat szabályozó jogi rendelkezések körében is megjelenjenek. ${ }^{62}$

Az általános személyiségi jog, mint az ember értékminőségének kifejeződése, olyan általános értéket testesít meg, amelynek garanciális védelmét alkotmányosan nem lehet a személyiséget alkotó egyes vonatkozások értékelésétől függővé tenni, hanem annak védelmét általánosan, s a személyiség tartalmi elveit tekintve egyenlően kell a törvényi szabályozás szintjén biztosítani. ${ }^{63}$

A régi Ptk. ${ }^{64}$ alapján az emberi méltóság joga csak egy példálózó felsorolásban, mintegy a személyiség egyik szegmenseként nevesített személyiségi jogként jelent meg. Igazi előrelépést jelentett a hatályban lévő Ptk. azon rendelkezése ${ }^{65}$ amely a személyiségi jogok generálklauzulájának megfogalmazásával az emberi személyiség magánjogi védelmének középpontjába az emberi méltósághoz való jogot állította. ${ }^{66}$ Álláspontom szerint a Polgári Törvénykönyv e szabályozási konstrukciója legitim alapot jelent a személyiségi jogok katalógusának bővítéséhez.

A kérdés magától értetődő: értelmezhető-e a kapcsolattartási jog az emberi méltósághoz füződő jog dimenziójában? A bírói gyakorlatot áttekintve számos igenlő válasszal találkozhatunk, melyek a gyermekkel való kapcsolattartásra a személyiségi lét alapvető megnyilvánulásaként tekintenek ${ }^{67} \mathrm{~A}$ szülöi kapcsolattartási jog ugyanis szorosan kapcsolódik az emberi individuumhoz, annak lényegét képezi, azt a sze-

\footnotetext{
59 Ptk. 2:42. § (1) „Mindenkinek joga van ahhoz, hogy törvény és mások jogainak korlátai között személyiségét, így különösen a magán- és családi élet, az otthon, a másokkal való - bármilyen módon, illetve eszközzel történő - kapcsolattartás és a jóhírnév tiszteletben tartásához való jogát szabadon érvényesíthesse, és hogy abban őt senki ne gátolja."

${ }^{60}$ A magánélet védelméröl szóló 2018. évi LIII. törvény 1. §, 11. §.

${ }^{61}$ LÁBADY: Alkotmányjogi hatások... i. m., 19.

62 Fővárosi Ítélőtábla 32.Pf.21.229/2017/5-II.

63 34/1992. (VI. 1.) AB határozat, ABH 1992, 192, 4.3. pont.

${ }^{64}$ A Magyar Köztársaság Polgári Törvénykönyvéröl szóló 1959. IV. törvény.

65 Ptk. 2:42. § (2) „Az emberi méltóságot és az abból fakadó személyiségi jogokat mindenki köteles tiszteletben tartani. A személyiségi jogok e törvény védelme alatt állnak."

9266 LÁBAdY Tamás: Az emberi személy az új Polgári Törvénykönyvben. lustum Aequum Salutare, 2015/3, 142.

${ }^{67}$ Pécsi Ítélőtábla Pf.VI.20.037/2018/7.
} 
mélyiség megnyilvánulásaként, kibontakoztatásaként kell értelmezni. ${ }^{68} \mathrm{~A}$ Fövárosi Ítélőtábla álláspontja szerint a gyermek világra jöttével ugyanis az emberi minőség speciális formát, magasabb minőséget ölt. A szülőnek olyan újabb jogai és kötelezettségei keletkeznek, amelyek szorosan kötődnek emberi minőségéhez, függetlenül attól, hogy a szülök házassága, vagy az élettársak életközössége fennáll-e. Ezen jogok - közöttük a szülőnek a gyermekkel való kapcsolatához füződő joga - sérelmét okozó olyan magatartás, amely külső szemlélő számára is érzékelhető, egyértelmüen személyiségi jogot is sért. ${ }^{69}$

A Fővárosi İtélőtábla a kapcsolattartás jogát a családi élethez füződő jogból is levezethetőnek tartja. A család (alkotmányos) védelme ugyanis nemcsak a házasságon alapuló családra, hanem a szociológiai értelemben vett családi életre is vonatkozik. ${ }^{70}$ Ebböl az következik, hogy a szülők és a gyermekek nem csupán a teljes családok esetében rendelkeznek olyan, részletesen nem definiálható jogokkal, amelyek a családi élethez füződő jogok gyüjtőfogalma alá tartoznak. Ezek egyike az a jog, hogy a szülő a gyermekével a házasság felbontása, vagy új család alapítása esetén is a lehető legszélesebb körben tarthassa a kapcsolatot. Minden olyan magatartás, amely ezt a jogot jogellenesen korlátozza, csak időlegesen vagy hosszabb időszakra ellehetetleníti, sérti az illető személyiségi jogát. ${ }^{71}$

Szintén a családi és magánélethez füződő joggal összefüggésben emelte ki a Fövárosi Ítélőtábla - osztva az elsőfokú bíróság álláspontját ${ }^{72}$ - a nagyszülőket megillető kapcsolattartási jog személyiségi jogi voltát. Magától értetődő, hogy a családi és magánéletnek szerves része a közeli hozzátartozókkal személyes vagy nem személyes kapcsolatok megtartása vagy fejlesztése. Ebből kifolyólag a családi kapcsolatok zavartalan ápolása, megélése nem elkülönült, hanem az Alaptörvény által is védett, a Ptk. szerinti személyiségi jogok ${ }^{73}$ része. ${ }^{74} \mathrm{Az}$ unokával való nagyszülői kapcsolat, ${ }^{75}$ annak megélése és kialakítása a nagyszülő személyiségének lényegi ismérvei közé tartozik. Ezen családi kapcsolatba, ennek alakításába történő olyan beavatkozás, amely a vitás helyzetekkel együtt járó kisebb sérelmeket meghaladja, az emberi méltóság mint általános személyiségi jogból fakadó magánélet és családi élethez való jog sérelmét, ezáltal a személyiségi jog sérelmét is megvalósítja. ${ }^{76}$

Egy másik megközelítés szerint a kapcsolattartás joga a teljes és egészséges családban éléshez füződő személyiségi jogból származtatható. A Debreceni Törvényszék határozatában kifejtette, hogy az általános személyiségi jog részét képezik a jogszabályokban nevesített, és a jogszabályokban nem nevesített, a bírói és alkotmánybírói gyakorlat által kidolgozott egyes személyiségi jogok. llyen, nem nevesített

\footnotetext{
${ }^{68}$ Győri Ítélőtábla Pf.III.20.200/2018/6.

${ }^{69}$ Fővárosi Ítélőtábla 32.Pf.21.229/2017/5-II.

70 14/1995. (III. 13.) $A B$ határozat, $A B H 1995$ 82. 154/2008. (XII. 17.) AB határozat, $A B H 2008,1203.32 / 2010$. (II. 25.) $A B$ határozat, $\mathrm{ABH} 2008,1203$.

${ }^{71}$ Fővárosi Ítélőtábla 32.Pf.21.229/2017/5-II.

72 Budapest Környéki Törvényszék 21.P.20.049/2017/13.

${ }^{73}$ Ptk. 2:42. § (1).

74 Fővárosi Ítélőtábla 32.Pf.20.412/2018/10-II.

${ }^{75}$ A nagyszülőt megillető kapcsolattartási jogról a Ptk. 4:179. § rendelkezik.

${ }^{76}$ Kúria Pf.32.20412/2018/10.
} 
személyiségi jognak minősül a teljes és egészséges családban éléshez füződő személyiségi jog, amely magában hordozza a családtagokkal fenntartott kapcsolathoz füződő személyiségi jogot. ${ }^{77}$

Egyetértek azon álláspontokkal, amelyek az emberi méltósághoz, valamint a magán- és családi élethez füződő joggal összefüggésben emelik ki a kapcsolattartási jog személyiségi jogi minőségét. Meglátásom szerint a kapcsolattartás - mind a gyermek, mind pedig a szülő vonatkozásában - az emberi lét esszenciális eleme, amely nem lehet a szülők házasságának, vagy az élettársak életközösségének függvénye. Nem értek egyet azonban azon bírósági állásponttal, amely a kapcsolattartási jogot a teljes és egészséges családban éléshez fűződő jogból származtatja. Véleményem szerint ez utóbbi valamely (közeli) hozzátartozó elvesztése vagy súlyos sérülése kapcsán értelmezhető. ${ }^{78}$

Az eddig bemutatott példák alapján egyértelmüen kijelenthető, hogy a kapcsolattartás jogával összefüggésben számos bírói fórum lehetőséget lát személyiségi jogi igény érvényesítésére. Eltérő az álláspont azonban a tekintetben, hogy az igényérvényesítés a családjogi szabályok útján történő perindítás sikertelenségétől független, vagy feltételezi azt.

A Fővárosi Ítélőtábla gyakorlata alapján a családjogi szabályok útján történő igényérvényesítéstől függetlenül indokolt a kapcsolattartás személyiségi jogi perben történő érvényesítése. A Fővárosi Ítélőtábla következetes álláspontja ugyanis az, hogy személyiségi jogi igényként az igények akkor érvényesíthetők, ha a védendő érték közvetlenül az ember személyiségéből fakad. ${ }^{79}$ A szülő és a gyermek közötti kapcsolattartás ilyen igény, egyike az emberi individuumhoz legszorosabban kapcsolódó jogoknak, ${ }^{80}$ hiszen a személyiség részét képezi az, hogy a szülő a gyermekével milyen kapcsolatot tud tartani. ${ }^{81}$

Ezt az álláspontot a Legfelsőbb Bíróság is megerősítette, megállapítva, hogy önmagában az, hogy a házastársak belső jogviszonyában a házastársak egymással szemben tanúsított, jogellenes magatartása esetében a jogvédelmet elsősorban a családjog intézményei biztosítják, nem zárja ki az okozott sérelem miatt a személyiségi jogvédelmi igény érvényesíthetőségét - amint azt a Legfelsőbb Bíróság a Pf.Il.25.983/2001/7. számú határozatában ${ }^{82}$ a gyermek és a szülő közötti kapcsolattartás akadályozása miatti jogsérelem esetén megállapította. ${ }^{83}$

Némileg eltérő álláspont látszik azonban kirajzolódni a Bírósági Döntések Tárában 2018-ban közzétett egyik határozatból, amely a családjogi szabályok körében történő igényérvényesítést teszi elsődlegessé. Ez alapján a szülő és a gyermek kap-

77 Debreceni Törvényszék 6.P.20.791/2013/27.

${ }^{78}$ A teljes és egészséges családban éléshez füződő jog a hozzátartozói igények körén belül értelmezhető. FÉZER: i. m., 234-250.

79 BDT 2015. 3337.

${ }^{80}$ Fővárosi Ítélőtábla 2.Pf.20.996/2016/4.

${ }^{81}$ Fővárosi Ítélőtábla 32.Pf.21.094/2016/5-II., 2.Pf.20.272/2018/8., 2.Pf.21.473/2017/5/II., 2.Pf.20.272/2018/8.

82 Legfelsőbb Bíróság Pf. II. 25.983/2001/7.: „A gyermek a különélő szülőjénél való kapcsolattartásának jogellenes korlátozása miatt, személyiségi jogai sérelmére hivatkozással nem vagyoni kártérítést a polgári jog általános szabályai alapján követelhet."

${ }^{83}$ Kúria Pfv.IV.21.171/2009/4. 
csolattartásának zavartalansága - függetlenül a családjog részletes szabályozásának tényétől - személyiségi jogi alapon is vizsgálható, ha az érintett szülő minden lehetséges jogorvoslatot igénybe vett, ${ }^{84}$ továbbá a másik szülő rendszeresen és tartósan akadályozza a jogának gyakorlását. ${ }^{85}$

Az eddig vázoltakkal ellentétben számos olyan határozat is született, amely elvi éllel elveti a kapcsolattartási jog személyiségi jogi voltát. Az ezen határozatokat hozó bíróságok álláspontja szerint a kapcsolattartási jog - a családi élet körében kétségkívül értelmezhető emberi jogi, illetöleg alkotmányos alapjogi dimenzióban, azonban nem illeszthető be a személyiségi jogok katalógusába. Álláspontjuk szerint a kapcsolattartási jog tehát alapvető alkotmányos alapjog, de nem minősül közvetlenül személyiségi jognak. ${ }^{86}$

A Debreceni Ítélőtábla a családi élet tiszteletben tartásához füződő emberi, illetve alapjoggal összeegyeztethetőnek tartja a kapcsolattartási jogot, a teljes és egészséges családban éléshez füződő joggal való kapcsolódását azonban vitatja. Álláspontja szerint a bírói gyakorlat az egészséges családban élés jogát a fogyatékossággal született gyermek szüleit ért immateriális sérelem, míg a - káresemény előtti állapothoz történő viszonyítás céljából használatos - teljes családban élés jogát a káresemény következtében megszünő családi szerep, illetve családi funkció kompenzálhatósága végett dolgozta ki. ${ }^{87}$ Ezen érvek mentén a kapcsolattartási jogot nem tartja levezethetőnek a „teljes” és „egészséges” családi kapcsolatokhoz füződő, nem nevesített személyiségi jogból. ${ }^{88}$

A Szegedi Törvényszék meggyőződése szerint a Ptk. az alkotmányos alapjogok és a polgári jog kapcsolata körül kialakult elméleti vita kapcsán azt az álláspontot követi, hogy a polgári jogi személyiségvédelem köre nem azonos az alapjogok katalógusával. Kétségtelen, hogy bizonyos alapjogok (például az élethez, a testi épséghez, az egészséghez füződő jogok) megsértése a személyiségi jogok magánjogi védelme körében is szankcionálható, de ezeknél is eltérőek az érvényesítésüket szolgáló jogi eszközök. Ennek megfelelöen a törvény el kívánja kerülni azt, hogy az alkotmányos szabadságjogok, valamint a nemzetközi egyezményekbe foglalt emberi jogok közül azokat is a magánjogi kódex tartalmazza, amelyek érvényesülését az államnak közjogi eszközökkel kell biztosítania, $s$ amelyek védelmére a polgári jogi eszközök egyáltalán nem, vagy csak kevéssé alkalmasak. ${ }^{89} \mathrm{~A}$ Kúria kialakult gyakor-

\footnotetext{
${ }^{84} \mathrm{Az}$ irányadó tényállás szerint már a per során számtalan konfliktus adódott a gyermek kapcsolattartásával összefüggésben, amelyek a jogerős ítéletet követően sem szűntek meg. A per felperese számos alkalommal fordult a gyámhivatalhoz annak megállapítása érdekében, hogy egyes kapcsolattartások az alperes hibájából hiúsultak meg, kérte azok pótlásának elrendelését. A gyámhivatal a kérelmek egy részét formai okokból elutasította, valamint azért, mert a felperes nem a bírósági döntéseknek megfelelő időben kívánta gyakorolni jogait. Több határozat azonban az alperest marasztalta. A felek között olykor tettlegességig fajuló konfliktusok voltak kifejezetten a kapcsolattartással, annak megvalósítási módjával összefüggésben. A gyermek átadásaátvétele miatt támadt problémák rendezéséhez a felperes gyakran rendőri segítséget kért. Jól látható tehát, hogy az alperes a közigazgatási jog által nyújtott lehetőségeket igénybe vette - sikertelenül.

85 BDT 2018. 3822.

${ }^{86}$ Kúria Pfv.IV.21.733/2017/8.

87 EBH 2009. 2043., Kúria Pfv.III.20.792/2011/5.

88 Debreceni Ítélőtábla Pf.I.20.415/2014/6.

${ }^{89}$ Szegedi Törvényszék 1.P.21.530/2017/16.
} 
lata alapján a személyiségi jogi perek csak a jogrendszerben betöltött helyüknek és szerepüknek megfelelően alakíthatják az életviszonyokat. ${ }^{90}$

Ezen felfogással összhangban a Győri Törvényszék hangsúlyozta, hogy a személyiségi jog és a személyhez kötődő igény nem esik egybe. Napjainkra egyre elterjedtebbé vált az a gyakorlat, amely alapján a perbeli felek a keresetlevelek különböző tényelőadáshoz személyiségi jogokat illesztenek, azok megsértésére hivatkoznak, és ennek megfelelően személyiségi jogi igényt kívánnak érvényesíteni. Ezen gyakorlat ellenére a személyiségi jogok védelméhez kapcsolódó igények köre nem értelmezhető kiterjesztően, a más jogterületen szabályozott jogok és kötelezettségek és az ehhez kapcsolódó igények helyébe, mellé személyiségi jogi igény nem léphet. Amennyiben a hivatkozott jogsértés külön meghatározott jogterületre vonatkozó szabályozás körébe tartozik, ${ }^{91}$ úgy a jogsértés nem minősül egyben személyiségi jogsértésnek is. ${ }^{92}$

Következetes és egyértelmű a gyakorlat abban, hogy a személyiségi jogi per nem szolgálhat (bármely) más jogterületre tartozó jogvita eldöntésére, de még véleményezésére sem. A láthatás és kapcsolattartás szabályozására egyértelműen a családjogi jogintézmények szolgálnak, a végrehajtásról pedig - a közigazgatási jog szabályai szerint - a gyámhatóság köteles gondoskodni. ${ }^{93} \mathrm{~A}$ Ptk. Negyedik könyvében található, a családjog által szabályozott jogosultságok korlátozása nem eredményezi automatikusan valamely személyiségi jog megsértését, személyiségi jogi jogsértés csak abban az esetben állapítható meg, ha a jogsértő magatartás által előidézett változás az életvitel valamely jelentős aspektusának átmeneti vagy tartós, nagyfokú és negatív változását eredményezi. ${ }^{94}$ Ellenkező jogi álláspont elfogadása a Kúria megítélése szerint a jogrendszer egyfajta megkettőződéséhez vezetne.

A Győri Törvényszék meglátása szerint a személyiségi jogok az adott személyiség védelmére szolgálnak, a jogosult személyiségének lényegi vonásaihoz kötődnek. Ezek a jogok abszolút szerkezetủ jogok, amelyeket mindenki köteles tiszteletben tartani. ${ }^{95} \mathrm{~A}$ Debreceni Ítélótábla azt az álláspontot képviseli, miszerint a gyermek és a külön élő szülő közötti kapcsolattartás, mint relatív ${ }^{96}$ személyiségi jogviszony, a személyiségi jogok megsértésének jelenleg hatályos objektív szankciórendszerében nem értelmezhető, az objektív szankciók ugyanis felróhatóságtól függetlenül alkalmazandóak, azaz a jogsértés ténye minden további vizsgálódás nélkül kiváltja

\footnotetext{
90 Kúria Pfv.IV.20.445/2015/4.

91 Ezen megállapítás vitatható a magánélet védelméről szóló 2018. évi LIII. törvény tükrében. A törvény 14. §-a rögzíti, hogy az, akit magánélethez való jogában megsértenek, a személyiségi jogi igényeken kívül külön törvényben meghatározottak szerint egyéb igényeket is érvényesíthet. Álláspontom szerint ez a rendelkezés alapján - tekintettel arra, hogy a kapcsolattartás joga a magán- és családi élethez füződő jog egyik szegmense - lehetővé teszi a többszörös igényérvényesítést.

92 Győri Törvényszék P.20.629/2017/9., Fővárosi Ítélőtábla 17.Pf.20.919/2018.4-II.

${ }_{93}$ Kúria Pfv.IV.20.445/2015/4.

94 Fővárosi Törvényszék 17.Pf.20.919/2018/4-II.

${ }^{95}$ Győri Törvényszék P.20.629/2017/9.

${ }^{96}$ Már az 1898-as magyar Általános Polgári Törvénykönyv tervezete is bevezette az ún. személyi családjog fogalmát, s ez a gondolat a jogirodalomban több formában is megjelent, relatív személyjogok vagy relatív személyiségi jogok kifejezés alatt. SzÉKELY László: A személyiségi jogok hazai elmélete - A forrásvidék. ELTE Eötvös Kiadó, Budapest, 2011, 109.
} 
a szankciót. A relatív személyiségi jogok esetében írt kölcsönösség ugyanakkor a jogviszonyban részt vevő valamennyi fél - a kapcsolattartási jog esetében a gyermek, a külön élő és a gyermekkel együtt élő szülő - magatartásának az együttes vizsgálatát tenné szükségessé; ezt a személyiségvédelem jelenlegi polgári jogi szankciórendszere nem teszi lehetővé. ${ }^{97}$

Hasonló érvek mentén a Kaposvári Törvényszék is kiemelte, hogy a családjogi viták, így a külön élő szülőnek a gyermekkel való kapcsolattartás problémái nem személyiségi jogi vitában rendezhetőek, ${ }^{98} \mathrm{~s}$ az ezzel kapcsolatos esetleges szankciók alkalmazása is a családjog körébe tartozik. ${ }^{99}$

Mindent összevetve a kapcsolattartási jog személyiségi jogi minősége közel sem evidens. A Kúria frissen közzétett, 2018-as döntése egyértelmüen elveti a kapcsolattartási jog személyiségi jogi elismerését, s ezt az álláspontot képviselte több - fentebb ismertetett - határozatában a Debreceni Ítélőtábla is. Ezzel szemben a Fővárosi Ítélőtábla - szinte kivétel nélkül - azt hangsúlyozza, hogy a magánélethez füződő jog alkotmányos és családjogi határai egyre inkább összemosódnak, így a családjogi viszonyok védelme belefér a magánélethez való jog széles fogalmába. ${ }^{100}$

Véleményem szerint indokolt lenne a kapcsolattartási jog személyiségi jogi mivoltára vonatkozó következetes bírói álláspont kialakítása, amely eloszlatja a jogintézmény körüli (jog)bizonytalanságot.

Egyetértek azon álláspontokkal, amelyek alapján a magánjogi szabályozás konkrét rendelkezéseit és alapelveit lehetetlen az alkotmányos követelményektől elszigetelten alkalmazni. ${ }^{101}$ Ennek ellenére célszerütlennek tartom az alapjogok és a személyiségi jogok kategóriájának „összemosását”, s osztom azon álláspontokat, amelyek elutasítják a kapcsolattartás személyiségi jogi voltát. Véleményem szerint a családjogi szabályok megfelelő módon és mértékben biztosítják a kapcsolattartási jog magánjogban (polgári jogban) megvalósuló védelmét. Meglátásom szerint a személyiségi jogok alkotmányos alapjogokra való kiterjesztése a személyiség fogalmát megfoghatatlanná, a személyiségi jogvédelmet pedig olyan roppant nagyságú gyűjtőmedencévé tenné, amelyben minden emberi sérelemre orvoslást lehetne keresni. ${ }^{102}$

\section{4. Összegzés}

A tanulmány alaptézise - amely szerint a kapcsolattartási jog magánjogi és közjogi természetű is egyben - álláspontom szerint bizonyítást nyert. A kapcsolattartási jog komplexitását igazolja az a tény, hogy azt számos jogterület - többek között a polgári jog, az alkotmányjog és a közigazgatási jog is - szabályozási tárgykörébe vonja.

\footnotetext{
${ }^{97}$ Debreceni Ítélőtábla Pf.I.20.677/2016/5.

98 Kaposvári Törvényszék 24.P.21.234/2015/29.

99 BH 2018. 222.

100 Szabó Klára: Az új Ptk. a Fővárosi Ítélőtábla gyakorlatában. Polgári Jog, 2018/11-12, 7.

101 GADó Gábor: Alapjogok védelme az új Polgári Törvénykönyvben. Fundamentum, 2010/1, 22.

102 Petrik: i. m., 35.
} 
A vizsgált jogintézmény alapjogi minősége kétségbevonhatatlan, ezt támasztja alá többek között az Alkotmánybíróság egyértelmű és következetes gyakorlata, valamint az a tény, hogy a kapcsolattartási jogra számos esetben még a polgári bíróságok is alkotmányos jogként hivatkoznak. ${ }^{103}$

A kapcsolattartási jog személyiségi jogi rangra történő emelése ezzel szemben ellentétes álláspontok kereszttüzében áll: ennek megfelelően, amennyiben a kapcsolattartási jog, mint alapjog, individuális jogsértéssé transzformálódik, elsődlegesen a családjogi szabályok útján indokolt az igényt érvényesíteni, a személyiségi jogi jogsérelem, mint hivatkozási alap - ahogyan az a rendes bíróságok gyakorlatát áttekintve kirajzolódott - nem feltétlenül állja meg a helyét.

Habár a kapcsolattartási jognak az emberi méltósághoz füződő joggal, valamint annak egyes aspektusaival - így például a személyiség szabad kibontakoztatásához, valamint a magán- és családi élethez füződő joggal - fennálló immanens kapcsolata magától értetődő, ennek ellenére a bíróságok számos esetben azt hangsúlyozzák, hogy a személyiségi jogvédelem nem szolgálhat a családon belül felmerülő, a családi kapcsolatok kialakítására vonatkozó konfliktusok feloldására - így többek között a szülő és a gyermek közötti kapcsolattartási jog érvényesüléséből fakadó problémák rendezésére sem.

További polémiát idéz elő - mind a jogirodalomban, mind pedig a joggyakorlatban - az alapjogvédelem és a személyiségi jogvédelem egymással fennálló kapcsolatára vonatkozó egységes álláspont kialakítása is. Több, vizsgálat tárgyává tett bírósági határozat kiemelte, hogy a polgári jogi személyiségvédelem köre közel sem azonos az alapjogok katalógusával, célszerütlen tehát az alapjogi és a személyiségi jogi katalógus párhuzamba állítása.

Úgy vélem, hogy az alapjogvédelem és a személyiségi jogvédelem kapcsolatát övező elméleti vita feloldódhat, amennyiben elfogadjuk, hogy az Alaptörvénynek „lámpásként”, azaz igazodási pontként kell irányt mutatnia az állami szervek múködésének és a jogalkotásnak, másrészt „kovászként”, belefolyva az állam és a társadalom szöveteibe, erjesztenie kell a jogállamiság eszméjét az állami és a társadalmi élet minden területén és a polgárok életében, azaz a magánautonómia viszonyaiban is. ${ }^{104} \mathrm{Az}$ alkotmányjog és a polgári jog célja jelen esetben egy és ugyanaz: a gyermek védelme, érdekeinek érvényre juttatása.

A jogi szabályozás sokrétűsége ellenére - álláspontom szerint - indokolt lenne a kapcsolattartási jog személyiségi jogi minőségére vonatkozó egységes jogirodalmi - és legfőképp - bírói álláspont kialakítása, mely segítene eloszlatni a kapcsolattartási jog érvényesítésére jellemző bizonytalanságot.

103 BH 2001. 230. (Legfelsőbb Bíróság Pfv. II. 21.616/1999.): „A gyermek nemzetközi egyezményekben deklarált, alkotmányos joga, hogy különélő szülőjével kapcsolatot tarthasson akkor is, ha más országban él."

104 LÁBADY: Alkotmányjogi hatások... i. m., 14. 


\begin{abstract}
It is self-evident that parents play an irreplaceable role in the lives of their children, influencing the child's physical, mental, and emotional well-being and behavior. It is therefore necessary that children maintain personal relations and direct contact with each parent, even if the marriage of his/her parents is permanently and irreparably damaged. The right to contact, which has a strong legal foundation in international conventions, is traditionally described as a right of the child, despite the fact that contact between parent and child is both a right and obligation of mothers, fathers and children. The right to contact is a Janus-faced, complex legal institution: although it is largely based on the fundamental right to private and family life guaranteed by constitutional norms, it plays a significant role in private law disputes as well. The aim of this article is to present the place of the right to contact within the Hungarian legal regime, emphasizing the enforcement of this right in the field of protection of basic and personality rights.
\end{abstract}

